\title{
EXAMINATION OF THE RELATIONSHIP BETWEEN TEACHERS' QUALIFICATIONS TO USE OF 21st CENTURY SKILLS AND TEACHERS' LEVELS OF READINESS FOR CHANGE
}

\author{
Nevin Demir Çavuş̧ii, \\ Mehmet Akif Helvaci ${ }^{2 i i}$ \\ ${ }^{1}$ Literature Teacher, \\ State School, \\ Turkey \\ 2Prof. Dr., \\ Faculty of Education, \\ Uşak University, \\ Turkey
}

\begin{abstract}
:
The aim of this study is to reveal the relationship between the competence of using 21st century skills and readiness for change of primary and secondary school teachers working in public schools in Uşak. The research was designed in scanning model. The population of the research consists of 3972 teachers and 498 school administrators working in primary and secondary schools in Uşak, and the sample consists of 640 teachers and 82 school administrators. Convenience sampling was used in the selection of the sample. In order to collect data, "21st Century Teaching Skills Scale" developed by Orhan-Göksün (2016) and "School Readiness for Change Scale" developed by Helvac1 (2015) were used. As a result of the research, according to the opinions of the teachers and school administrators, the competency of using 21st century skills of the teachers is at "high" level, according to the opinions of the teachers, the level of readiness for change is at the "high" level, and according to the opinions of the school administrators, the level of readiness for change of the teachers is at the "moderate" level. It has been determined that there is a positive and highly significant relationship between teachers' 21st century skills usage competencies and their readiness for change skill levels.
\end{abstract}

Keywords: 21st century skills use competencies, readiness for change, teachers

\section{Introduction}

The incorporation of scientific breakthroughs into the manufacturing sector, as well as the fact that industry and automation systems have become artificial intelligence-

${ }^{i}$ Correspondence: email nevindemircavus@gmail.com 
centered in the twenty-first century, has allowed us to benefit from their abilities. Because the notion of 21st-century talents is so crucial in social life, those who will create the future must be able to design, produce, control, and work in technology (Aydeniz, 2017). A new era is dawning, marked by changes in production processes, management, the economy, technology, and social life. It is vital to make changes in the field of education in order for societies to adapt to the conditions of this new century. Changes in schools, or educational organizations, are necessitated by agreements that a society has made with another society or societies (Helvac1, 2005).

The approach known as 21st century skills, which is regarded vital for individuals to stay current, is at the core of current education discussions, and educational organizations that will teach these skills to students must be open to change.

When the classifications on which this research is based and that are frequently used in the field of 21st century skills examined, some common and different aspects emerge. In all classifications, communication, cooperation, knowledge, social and cultural skills, citizenship, media and technology skills appear as common skills. Creativity, problem solving, critical thinking, creating quality products are most popular in classifications. For individuals to lead a more qualified life, they need to have the aforementioned skills and these skills should be gained through education. As a natural consequence of this, these skills should be included in education programs (Anagün, Atalay, Kılıç ve Yaşar, 2016). These skills to be gained by individuals are transmitted by teachers in educational organizations, therefore it is important that teachers are equipped with these skills in accordance with the requirements of the era. In the current education system in Turkey, the training of teachers in order to contribute to the professional development of teachers in order to support them with various in-service training seminars and to raise students equipped with the skills appropriate for the age is very important. The Ministry of National Education carries out studies to determine the training needs and to meet these needs. However, it is very important for teachers to be eager and ready for these changes in order to keep up with the changing system, to update their qualifications and to be productive. Teachers who are ready for change can train individuals equipped with the 21st century skills by improving themselves personally and professionally in order to acquire new skills. In this concept, the aim of this research is to examine the relationship between teachers' ability to use 21st century skills and their level of readiness for change.

\section{Literature Review}

Revolutionary changes and developments can be seen in the information era. Rapid information diffusion, advances in information technology, increased product consumption, increased interest in personal and societal needs, and the gradual transformation of the world into a global village have all made it imperative for 21stcentury cultures to evolve (Helvac1, 2015). It is possible for individuals to keep up with these changes and transformations in the 21st century through education, and the main 
goal of the education in the information society is to raise individuals who can find solutions to problems, renew and update themselves, seek and question for information. According to Günbayı (2006), the infrastructure of education should be updated in line with these purposes and teachers should be trained to implement this structure effectively. By reorganizing the schools, which are the most important elements of the education system, in accordance with the changing conditions and transforming them into learning schools, the determined goals will be achieved effectively (Parlar, 2012).

Although there is not a joint definition for 21st century skills, it may be conceptualized as learning and renewal, knowledge, media and technology, life and career skills that are generally required by individuals. These skills have been classified differently by many institutions and organizations with similar characteristics.

While the teacher was at the center of education system in past, an education system has emerged that puts the student in the center is necessary in line with the changing educational needs with the transformation towards the understanding of technopedagogical content knowledge. When the 21st century skills are taken into consideration, a system in which students are at the center of education as well as determine their educational goals and in which the teachers act as a guide while achieving them becomes important. The teacher should develop an understanding that puts the student in the center and prioritizes moral values. Rather than teaching a subject within the framework of a single point of view in the learning environment, it should be able to regulate the conditions for reaching this goal in accordance with the interests and skills of each individual and targeting individuals.

The most important role of teachers in the information society is to take the students to the center and teach them how to access and benefit from information in proper situations. Teachers should be able to provide basic knowledge to students. This means learning to learn for the individual. However, the teacher should know the student well, offer learning opportunities suitable for his/her learning situation and style, facilitate learning for his/her student and direct him/her to the right one (Numanoğlu, 1999).

Teachers who have a great function in the new understanding of education should be open to innovation, see the change and development in a timely manner and constantly update their knowledge. Otherwise, they will not be able to prepare the students for the era in which they will live. Teachers should be a guide to access information rather than a source of information, they should be the new generation teachers who teach learning (Parlar, 2012).

The most important feature that defines the age we live in is change. Changes in the economic, cultural, social and technological structure have brought many innovations. An intense and rapid change process is taking place at a universal scale. It is possible to say that this rapid change also takes place in the field of education. Today, education has ceased to be an activity that takes place within the boundaries of the educational environment and has become an endeavor carried out in communication 
with the environment. This change brought about the need for change in education (Çolakoğlu, 2005).

Educational institutions are the catalysts for the development of a Social Open System. Educational institutions should make every effort to best fulfill their functions in terms of influencing and being influenced by society. Educational institutions want teachers to be efficient and maintain a high level of performance in attaining goals and objectives that are appropriate for today's conditions, in accordance with the demands of the era. These goals appear to be achievable if instructors are motivated and school administrators have sufficient knowledge and abilities about motivational tactics (Helvac1, 2015).

It is quite difficult to implement a change that the teachers do not approve of or adopt during the change process. The goals of the change and the goals of the teachers must be compatible in order for teachers to adopt and accept the change. As a result, instructors should be involved in the decision-making process when it comes to change (Aydoğan, 2007).

The strategy for bringing about change in educational organizations is to transform the institution's organizational culture. It is extremely difficult to execute change without first changing the culture. The condition of innovation that occurs with change causes changes not only in the structure but also in the process and interactions; in educational organizations, the expected innovation scenario should be structural and behavioral (Terzi, 2007).

The teachers play a major role in the effectiveness of the training program in practice. The teaching profession is the one that is now undergoing the most transformation. Teachers carry out their tasks and responsibilities to the best of their abilities. Teachers' responsibilities have reflected the quick changes and advances of our time. These developments are reflected in educational programs, and instructors' duties have shifted as a result. Teachers should demonstrate individual traits such as the ability to use a variety of communication and education-teaching strategies, as well as the willingness to work in groups (Güven, 2001; Keser, 2000).

The inclusion of teachers in these procedures is necessary for the success of the reform process. At every stage of the transformation process, teachers' input, needs, and participation should be sought (Beycioğlu ve Aslan, 2010).

Because the twenty-first century is the age of information and technology, as well as a period of intense competition, all organizations should adapt quickly. Teachers' participation in change studies at the highest level is critical in terms of transforming, renewing, and updating the organizations with which they are linked (Yazicl, 2009).

Only when teachers, who are the major dynamics of education, take an active role and are at the core of change, educational reforms can be implemented. Teachers should keep their existing qualifications up to date and be open to changes and innovations in the field of education in light of this situation (K1lbaş, 2000).

Individuals have high expectations of teachers in terms of education from the systems that make up society. Teachers have always been role models for their students, 
as they are seen as the pioneers and transmitters of change and innovation. The transformation process will be lost from the start if the teacher does not accept and welcome the change. Because teachers will instill in their children the ideals they believe and know to be true in their classrooms. When the effects of teachers on students are taken into account, it becomes clear that a change plan that ignores them is not a good plan. As a result, involving teachers in the change process and soliciting their feedback are critical components of successful transformation (Akman, 2017).

\section{Research Objective}

The aim of the study is to examine the relationship between the use of 21st century skills of teachers working in Primary and Secondary Schools in Uşak and their readiness for change. In line with this general purpose, answers were sought for the following subproblems.

1) According to the teachers' opinions, what are the competencies of teachers to use 21st century skills?

2) According to the opinions of school administrators, what are the competencies of teachers to use 21st century skills?

3) What is the readiness level of teachers for change according to teachers' opinions?

4) According to the opinions of school administrators, what is the readiness level of teachers for change?

5) Is there a relationship between teachers' ability to use 21st century skills and their readiness for change?

\section{Material and Methods}

This section is grouped under four headings: research model, population and sample, data collection tool and data analysis.

\subsection{Research Model}

This study is a scanning model that aims to investigate the relationship between teachers' ability to use 21st century skills and their readiness for change in the province of Uşak.

Survey studies are defined by Büyüköztürk, Kılıç-Çakmak, Akgün, Karadeniz, and Demirel (2018) as the collecting of data to answer questions about a certain group. Because it is a matter of revealing an existing condition, this study was built with this paradigm.

\subsection{Population and Sample}

The population of the research consists of 3972 primary school teachers and 498 primary school administrators working in 214 schools in Uşak province (center and districts) in the 2020-2021 academic year. The sample of the research consists of 640 teachers working in 250 primary schools in Uşak and 82 administrators working in these schools. 
Convenient sampling method was used as the sampling method. Büyüköztürk et al. (2018) defined convenient sampling as a sampling method in which the researcher reaches the sample size, he needs in the easiest way by saving time, effort and cost. In this study, data were collected by sending the questionnaires to the administrators and teachers via Whatsapp groups, and by sending the online questionnaires to the administrators and teachers who agreed to participate in this research voluntarily through Google Questionnaires. While determining the sample size, the theoretical sample size chart (Balc1, 2011) was used. According to this chart, it was stated that the sample size required for a confidence level of 0.05 in studies with populations between 1000 and 4000 should be at least 350. However, in order to increase the reliability of the research, a questionnaire was applied to 640 teachers. In the context of school administrators in the universe, 82 school administrators voluntarily participated in the survey.

\subsection{Data Collection Instruments}

The data in the study were collected through a questionnaire. The survey consists of three parts. In the first part of the questionnaire, data on the demographic characteristics of the participants, in the second part, the opinions of the teachers on the use of 21st century skills, and in the third part, the opinions of the teachers on the level of readiness for change were collected. "Personal information form" was used to determine the demographic characteristics of the teachers. In order to determine the competence of teachers to use 21st century skills, the "21st Century Skills Scale" developed by Göksun (2016) was used. The scale consists of items in 5-point likert type. In the study, the items of the "Readiness for Change" sub-dimension of the "Schools' Readiness for Change Scale" consisting of 38 items developed by Helvac1 (2015) were used to determine the readiness levels of teachers for change. Teachers' readiness for change is determined by 7 items.

The Cronbach Alpha Coefficient was calculated for the reliability of the scales used in the questionnaire. As a result of this calculation, the results of the reliability analysis of all the scales and their sub-dimensions are as follows: The Cronbach Alpha Coefficient for teachers' readiness for change was found as $\alpha=.896$. Cronbach Alpha Coefficient for the whole of 21st Century Teacher Skills Use Scale $\alpha=.870, \alpha=.812$ for affirmative skills sub-dimension, $\alpha=.895$ for flexible teaching skills, $\alpha=.947$ for managerial skills, $\alpha=.947$ for technopedagogical skills $=.801$ and $\alpha=.762$ for productive skills. Büyüköztürk (2003) states that this value, which is calculated as the internal consistency coefficient, should be higher than .70 for reliability.

\subsection{Data Analysis}

The questionnaire used in the study consists of three parts. The first part of the questionnaire is aimed at taking the demographic characteristics of the teachers. The data collected from this section were subjected to descriptive analysis by calculating frequency and percentage using SPSS 22 statistical program. In the second part of the questionnaire used in the study, there are statements to determine the readiness level of teachers for 
change, and in the third part, there are statements to determine teachers' proficiency in using 21st century skills. In this sense, in the analysis of the relationship between the scales in the second and third sections of the questionnaire, the SPSS 22 statistical program was used to examine the normality of the distributions with the KolmogorovSmirnov test. Since the normal distribution condition was not met, the Spearman test, which is one of the non-parametric tests, was used.

\section{Findings}

In this section, the findings obtained from the last research are included.

The descriptive statistical results of the variables of duty, gender, years of service and graduation level related to the participants are given in Table 3.1.

Table 1: Descriptive Statistics Results for Participants' Demographic Variables

\begin{tabular}{|l|l|c|c|}
\hline Variables & f & \% \\
\hline \multirow{4}{*}{ Duty } & Teacher & 640 & 88.64 \\
\cline { 2 - 4 } & Administrator & 82 & 11.36 \\
\cline { 2 - 4 } & Total & 722 & 100 \\
\hline \multirow{5}{*}{ Gender } & Female & 421 & 58 \\
\cline { 2 - 4 } & Male & 305 & 42 \\
\cline { 2 - 4 } & Total & 726 & 100 \\
\hline \multirow{5}{*}{ Years of Service } & $1-5$ Years & 150 & 20.60 \\
\cline { 2 - 4 } & 6-10 Years & 166 & 22.80 \\
\cline { 2 - 4 } & $11-15$ Years & 166 & 22.80 \\
\cline { 2 - 4 } & $16-20$ Years & 148 & 20.40 \\
\cline { 2 - 4 } & 21 Years and More & 727 & 13.30 \\
\cline { 2 - 4 } & Total & 664 & 100 \\
\hline \multirow{3}{*}{ Graduation Level } & Under Graduate & 59 & 8.80 \\
\cline { 2 - 4 } & Graduate & 723 & 100 \\
\cline { 2 - 4 } & Total & & \\
\hline
\end{tabular}

As depicted in Table 1, when the duty of the participants in the research is considered, the majority of them are teachers $(88.64 \%)$; by gender the majority (58\%) are women; when examined in terms of years of service, the most $(22.80 \%)$ are those with $6-10$ years and 11-15 years of experience; According to the graduation status, it is seen that mostly $(91.80 \%)$ are undergraduate graduates.

According to the opinions of the teachers, the descriptive statistical values of the 21st century skills usage competencies of the teachers are presented in Table 2. 
Table 2: Teachers 21st Century Skills Use Competencies According to Teachers' Opinions

\begin{tabular}{|l|c|c|c|c|}
\hline 21st Century Skills Use Competencies & $\mathbf{N}$ & $\overline{\mathbf{X}}$ & $\mathbf{S S}$ & Level \\
\hline Affirmative Skills & 640 & 4,37 &, 60 & Very High \\
\hline Flexible Teaching Skills & 640 & 3,74 &, 87 & High \\
\hline Administrative Skills & 640 & 3,90 &, 69 & High \\
\hline Technopedagogical Skills & 640 & 3,86 &, 61 & High \\
\hline Productive Skills & 640 & 3,96 &, 77 & High \\
\hline Total & 640 & 3,93 &, 62 & High \\
\hline
\end{tabular}

Considering the results in Table 2, teachers consider themselves sufficient at the " very high" level in terms of the "affirmative skills" ( =4.37) sub-dimension in the context of 21st century skills. In terms of other sub-dimensions, they stated that they were sufficient at the "high" level. In addition, when evaluated in terms of sub-dimensions, it is understood that teachers have the most competence in the sub-dimensions of "affirmative skills" and "productive skills", and the least in the sub-dimensions of "flexible teaching skills" and "technopedagogical skills".

According to the opinions of the administrators, the descriptive statistical values of the 21st century skills usage competencies of the teachers are presented in Table 3.

Table 3: Teachers 21st Century Skills Use Competencies According to Administrators' Opinions

\begin{tabular}{|l|c|c|c|c|}
\hline 21st Century Skills Use Competencies & $\mathbf{N}$ & $\overline{\mathbf{X}}$ & $\mathbf{S}$ & Düzeyi \\
\hline Affirmative Skills & 82 & 4,08 &, 65 & High \\
\hline Flexible Teaching Skills & 82 &, 60 &, 92 & High \\
\hline Administrative Skills & 82 & 3,56 &, 75 & High \\
\hline Technopedagogical Skills & 82 & 3,68 &, 63 & High \\
\hline Productive Skills & 82 & 3,63 &, 85 & High \\
\hline Total & 82 & 3,66 &, 68 & High \\
\hline
\end{tabular}

Considering the results in Table 3, in the context of 21st century skills use competencies of teachers according to school administrators, teachers can use "affirmative skills" ( $=4.08$ ), "flexible teaching skills" (=3.60), "managerial skills" (=3.56), "technopedagogical skills". (=3.68) and "productive skills" (=3.63), at a high level. In addition, when evaluated in the context of sub-dimensions, according to the opinions of school administrators, it is seen that teachers have the most competence in the sub-dimensions of "affirmative skills" and "technopedagogical skills", and the least in the sub-dimensions of "managerial skills" and "flexible teaching skills".

The descriptive statistical values of teachers' readiness for change according to teachers' opinions are presented in Table 4. 
Table 4: Descriptive Statistical Values of Teachers'

Readiness for Change According to Teachers' Views

\begin{tabular}{|c|l|c|c|c|c|}
\hline No & Item & $\mathbf{N}$ & $\overline{\mathbf{X}}$ & SS & Level \\
\hline 1. & $\begin{array}{l}\text { Teachers have a high level of motivation towards innovation } \\
\text { initiatives in schools. }\end{array}$ & 640 & 3,60 & 0,89 & High \\
\hline 2. & $\begin{array}{l}\text { Teachers have a positive attitude that schools should be } \\
\text { restructured according to the needs of the age. }\end{array}$ & 640 & 4,00 & 0,87 & High \\
\hline 3. & $\begin{array}{l}\text { Teachers tend to try new teaching methods and techniques at } \\
\text { school. }\end{array}$ & 640 & 3,81 & 0,86 & High \\
\hline 4. & $\begin{array}{l}\text { Teachers evaluate the effects of developments in the world } \\
\text { (technological, social, cultural and economic) on the education } \\
\text { system. }\end{array}$ & 640 & 3,80 & 0,87 & High \\
\hline 5. & $\begin{array}{l}\text { Teachers participate in in-service training courses for school } \\
\text { improvement. }\end{array}$ & 640 & 3,50 & 0,98 & High \\
\hline 6. & $\begin{array}{l}\text { Teachers try to participate in activities such as symposiums, } \\
\text { congresses and workshops in order to be informed about the } \\
\text { developments in education. }\end{array}$ & 640 & 3,28 & 0,98 & Moderate \\
\hline 7. & $\begin{array}{l}\text { Teachers make effective use of information technologies in order to } \\
\text { be informed about educational developments. }\end{array}$ & 640 & 4,05 & 0,85 & High \\
\hline Total & 640 & 3,72 & .71 & High \\
\hline
\end{tabular}

When Table 4 is examined, it is understood that the teachers are sufficient at high level in terms of their readiness for change according to the opinions of the teachers.

The descriptive statistical values of teachers' readiness for change according to administrators' opinions are presented in Table 5.

Table 5: Descriptive Statistical Values of Teachers'

Readiness for Change According to Administrators' Views

\begin{tabular}{|c|l|c|c|c|c|}
\hline No & Item & $\mathbf{N}$ & $\overline{\mathbf{X}}$ & SS & Level \\
\hline 1. & $\begin{array}{l}\text { Teachers have a high level of motivation towards innovation } \\
\text { initiatives in schools. }\end{array}$ & 82 & 3,35 & 0,90 & High \\
\hline 2. & $\begin{array}{l}\text { Teachers have a positive attitude that schools should be } \\
\text { restructured according to the needs of the age. }\end{array}$ & 82 & 3,58 & 0,92 & High \\
\hline 3. & $\begin{array}{l}\text { Teachers tend to try new teaching methods and techniques at } \\
\text { school. }\end{array}$ & 82 & 3,41 & 0,84 & High \\
\hline 4. & $\begin{array}{l}\text { Teachers evaluate the effects of developments in the world } \\
\text { technological, social, cultural and economic) on the education } \\
\text { system. }\end{array}$ & 82 & 3,46 & 0,90 & High \\
\hline 5. & $\begin{array}{l}\text { Teachers participate in in-service training courses for school } \\
\text { improvement. }\end{array}$ & 82 & 3,11 & 0,99 & Moderate \\
\hline 6. & $\begin{array}{l}\text { Teachers try to participate in activities such as symposiums, } \\
\text { congresses and workshops in order to be informed about the } \\
\text { developments in education. }\end{array}$ & 82 & 2,90 & 1,08 & Moderate \\
\hline 7. & $\begin{array}{l}\text { Teachers make effective use of information technologies } \\
\text { in order to be informed about educational developments. }\end{array}$ & 82 & 3,76 & 0,77 & High \\
\hline Total & 82 & 3,37 & 0,69 & Moderate \\
\hline
\end{tabular}


When Table 5 is examined, it is understood that the teachers are sufficient at moderate level in terms of their readiness for change according to the opinions of the administrators.

The results of the relationship between teachers' 21st century skills use competencies and readiness for change competency levels are presented in Table 6.

Table 6: Spearman Test Results on Teachers' Competence

in Using 21st Century Skills and Readiness for Change Skills $(n=726)$

\begin{tabular}{|l|c|c|c|c|c|c|c|}
\hline Variable & A) & A1) & A2) & A3) & A4) & A5) & B) \\
\hline $\begin{array}{l}\text { A. 21st Century Skills Use } \\
\text { Competencies }\end{array}$ & 1 & & & & & & \\
\hline A1. Affirmative Skills &, $845^{* *}$ & 1 & & & & & \\
\hline A2. Flexible Teaching Skills &, $719^{* *}$ &, $567^{* *}$ & 1 & & & & \\
\hline A3. Administrative Skills &, $976^{* *}$ &, $814^{* *}$ &, $655^{* *}$ & 1 & & & \\
\hline A4. Technopedagogical Skills &, $909^{* *}$ &, $712^{* *}$ &, $584^{* *}$ &, $838^{* *}$ & 1 & & \\
\hline A5. Productive Skills &, $847^{* *}$ &, $694^{* *}$ &, $597^{* *}$ &, $818^{* *}$ &, $705^{* *}$ & 1 & \\
\hline B. Readiness for Change &, $777^{* *}$ &, $652^{* *}$ &, $567^{* *}$ &, $774^{* *}$ &, $699^{* *}$ &, $630^{* *}$ & 1 \\
\hline
\end{tabular}

${ }^{* *} \mathrm{p}<.01$

According to the Spearman test results in Table 6, a positive and highly significant relationship was found between teachers' 21st century skills use proficiency and readiness for change levels $\left(\mathrm{r}_{\mathrm{s}}=.777, p<.01\right)$. In addition, teachers' readiness for change skill levels and affirmative skills ( $\mathrm{rs}=.652, \mathrm{p}<.01$ ), flexible teaching skills ( $\mathrm{rs}=.567, \mathrm{p}<$ $.01)$, technopedagogical skills ( $\mathrm{rs}=.699, \mathrm{p}<.01)$ and productive skills ( $\mathrm{rs}=.699, \mathrm{p}<.01$ ) were found to be positively moderately significant. In addition, it has been observed that there is a positive and highly significant relationship between teachers' readiness for change skill levels and their managerial skills ( $r s=.774, p<.01)$ within the scope of 21st century skills use competencies. Accordingly, it can be said that as teachers' readiness for change skill levels increase, their competence in using 21st century skills will also increase.

\section{Results and Discussion}

This research was conducted to determine the relationship between teachers' 21st century skills usage competencies and their readiness for change competencies. As a result of the research, according to the opinions of the teachers working in public schools in the province of Uşak, it was determined that the teachers' competence in using 21st century skills is at high level. 21st century skills use competencies were examined in the dimensions of affirmative skills, flexible teaching skills, managerial skills, technopedagogical skills and productive skills, and it was concluded that teachers' 21st century skills use competencies were at the very high level in the dimension of affirmative skills and high in other sub-dimensions. These findings imply that, in the opinion of the teachers, teachers possess the abilities required in today's world. Secondary school pupils have a good degree of 21st century abilities, according to a 
survey conducted by Kaya (2017). It may be argued that in order for today's educational environments to keep up with change, teachers must be capable of appealing to today's pupils. Teachers are capable to respond to today's kids, according to the findings of this study. Data for secondary school instructors were acquired using the same data collection tool in the study conducted by Noise, Aslan, and Alçı (2020). As a result of the research, it was discovered that teachers' use of 21st century skills is high, and affirmative skills are one of the sub-dimensions with the greatest level in the context of sub-dimensions. Teacher candidates' levels of use of 21st century learner and 21st century teacher abilities were assessed in a study done by Orhan-Göksün (2016). As a consequence of the study, it was discovered that teacher candidates employ certain skill areas at a higher degree than the average. Furthermore, when sub-dimensions are analyzed, affirmative skills are determined to be the most important among teacher skills. As a result, the literature and the findings of this investigation are complementary. There were also other findings that did not completely match the literature. As a result, Karaman (2016) performed a study to investigate the association between pre-service teachers' media literacy levels and critical thinking skills. As a consequence of the study, it was discovered that pre-service teachers' critical thinking skills were poor and their media literacy was moderate.

As a result of the research, according to the opinions of school administrators, it was determined that the teachers' ability to use 21st century skills was at high level. 21st century skills use competencies were examined in the dimensions of affirmative skills, flexible teaching skills, managerial skills, technopedagogical skills and productive skills, and it was concluded that teachers' 21st century skills use competencies were at high level in all sub-dimensions. These findings imply that, in the opinion of school administrators, instructors possess the necessary abilities for today's age. These findings are consistent with the conclusions based on the opinions of the teachers who participated in the study. According to the teachers' opinions, the level of readiness for change of the teachers was at high level as a result of the research. These findings indicate that teachers are willing to adapt to changes in educational institutions. Furthermore, the findings of the teachers' proficiency in applying 21st century skills demonstrate parallelism with these findings, according to the opinions of the instructors within the scope of the research and the opinions of the school administrators. From this perspective, teachers will lead the way in altering the institution they are in because they are persons with the talents demanded by the age and are open to change. It may be said that it will make it much easier for school administrators to manage change in their institutions. According to the perceptions of teachers, schools; in the sub-dimensions of teachers, school administrators, physical and technological infrastructure, and parents, readiness levels for change were discussed in the research done by Helvacı and Kicıroğlu (2010). As a result of the research, it was concluded that the level of readiness in all sub-dimensions was moderate. In the study conducted by Zorlu (2017), it was found that the level of readiness for change of teachers is at high level according to the opinions of the teachers. Karacabey and Bozkuş (2018), in their study, examined the level of anxiety and readiness for change of school administrators. According to the findings, it has been revealed that school 
administrators are ready for change and their anxiety levels are higher than they should be. When considered in this context, it can be stated that the findings of the literature and this study have some similarities in terms of readiness for change, but show some differences in terms of readiness level.

According to school administrators working in public schools in Uşak, the level of readiness for change of instructors was assessed to be "moderate" as a result of the research. Teachers are relatively open to change in educational organizations, according to these findings. Furthermore, it was discovered that the teachers' level of readiness for change was at high level, according to the opinions of the teachers surveyed as part of the research. The cause for this can be described as being related to teachers' biased behaviour when evaluating themselves. According to the perceptions of school administrators, the level of readiness for change of instructors was at high level in the study done by Zorlu (2017). When seen in this light, the findings might be said to be mutually supportive.

As a result of the research, when the data obtained from the opinions of school administrators and teachers were evaluated together, it was seen that there was a positive and highly significant relationship between teachers' 21st century skills usage competencies and their readiness for change skill levels. In addition, there is a positive medium level between teachers' readiness for change skill levels and affirmative skills, flexible teaching skills, technopedagogical skills and productive skills within the scope of 21st century skills use competencies; On the other hand, it was concluded that there is a positive and highly significant relationship between managerial skills. Accordingly, it can be said that as teachers' level of readiness for change increases, their competence in using 21st century skills will also increase, or vice versa, as their competence in using 21st century skills increase, their level of readiness for change will also increase. In the study conducted by Kiyasoğlu (2019), the relationship between classroom teachers' 21st century teaching and learning skills was examined and it was determined that there was a positive and moderate relationship between the two variables. Gilıç (2015) conducted a research to examine the relationship between the level of participation of teachers in primary and secondary schools in decision making, the dominant school culture in their schools and the level of teachers' readiness for change. As a result of the research, it was concluded that there is a significant relationship between the level of participation of teachers in decisions and the level of readiness for change with the dominant school culture in their schools. It can be said that the findings of this study and the findings in the literature show some important similarities, although there are some differences in terms of the level of the relationship.

\section{Recommendations}

Based on the results obtained from the study, the recommendations for the research are as follows: 
1) According to the opinions of the teachers, it is understood that the teachers' ability to use 21st century skills is high. However, despite this, it is seen that teachers have the least proficiency in flexible teaching skills and technopedagogical skills, which are sub-dimensions of 21 st century skills usage competencies. Therefore, inservice training can be organized for teachers in the context of flexible teaching skills and technopedagogical skills.

2) According to the opinions of school administrators, it is understood that teachers have high proficiency in using 21st century skills. However, despite this, it is seen that teachers have the least competence in managerial skills and flexible teaching skills, which are sub-dimensions of 21st century skills use competencies. Based on this, in-service training can be organized for teachers in the context of managerial skills and flexible teaching skills.

3) According to the opinions of the teachers, it was determined that the level of readiness for change of the teachers was at a high level. However, it has been determined that teachers are moderately sufficient to participate in activities such as symposiums, congresses and workshops in order to be aware of the developments related to education and training. In this sense, it may be suggested by policy makers to take action to encourage teachers to participate in such activities.

4) According to the opinions of school administrators, it was determined that the readiness level of teachers for change was at "moderate" level. Accordingly, it may be considered to provide teachers with in-service training on this subject. Particularly, it is seen that teachers have very low proficiency in participating in in-service training courses for school improvement purposes and participating in activities such as symposiums, congresses and workshops in order to be aware of the developments related to education and training. In this sense, policy makers can take steps to find solutions by examining the reason for this situation

5) Considering that there is a positive and highly significant relationship between teachers' ability to use 21st century skills and their level of readiness for change, training, seminars, etc. to increase teachers' readiness for change skills and 21st century skills use competencies can be organized. Thus, it can be said that an increase in one variable will increase the other and increase productivity at school.

6) New studies can be conducted in different provinces examining the relationship between teachers' ability to use 21st century skills and their level of readiness for change.

7) Studies with larger samples can be conducted examining the relationship between teachers' proficiency in using 21st century skills and their level of readiness for change.

8) Studies can be conducted to examine the relationship between teachers' proficiency in using 21st century skills and their level of readiness for change through teachers working in private schools. 
This research was quantitatively designed. A qualitative study can also be done on a similar subject.

\title{
Conflict of Interest Statement
}

The authors declare no conflicts of interests.

\begin{abstract}
About the Author(s)
Nevin Demir Çavuş graduated from Trakya University, Faculty of Arts and Sciences, Department of Turkish Language and Literature in 2006. Later, in 2007, she completed the Non-Thesis Master's Program in Sakarya University Secondary Education Social Fields Education Turkish Language and Literature Teaching. She has taught Turkish Language and Literature at various public schools since 2008. Currently, she works as the Deputy Director of the Evening Art School and Teacher's House in Uşak. In 2019, she started her master's degree with thesis in Uşak University, Department of Educational Sciences, Department of Educational Administration and is still continuing.
\end{abstract}

\section{References}

Akman A, 2017. Sınıf öğretmenlerinin değişime direnç nedenlerinin incelenmesi. Yüksek Lisans Tezi, İstanbul Kültür Üniversitesi

Anagün, Ş S, Atalay, N, Kılıç, Z, ve Yaşar, S, 2016. Öğretmen Adaylarına Yönelik 21. Yüzyıl Becerileri Yeterlik Algıları Ölçeğinin Geliştirilmesi: Geçerlik ve Güvenirlik Çalışması. Pamukkale Üniversitesi Eğitim Fakültesi Dergisi, 40.40: 160-175

Aydeniz M, 2017. Eğitim sistemimiz ve 21. yüzyıl hayalimiz: 2045 hedeflerine ilerlerken, Türkiye için STEM odaklı ekonomik bir yol haritası. http://trace.tennessee.edu/cgi/viewcontent.cgi?article $=1019 \&$ context $=u$ tk theopu bs. Accessed 14 January 2021

Aydoğan, İ, 2007. Değişim Süreci ve Okul Personeli. GAU Journal Social \& Applied Sciences, 3.5: 13-24

Balcı, A, 2011. Sosyal bilimlerde araştırma yöntem, teknik ve ilkeler, Çankaya, Ankara, Türkiye

Beycioğlu, K, Aslan, M, 2010. Okul Gelişiminde Dinamik Olarak Değişim ve Yenileşme: Okul Yöneticileri ve Öğretmenlerin Rolleri. Yüzüncü Yıl Üniversitesi Eğitim Fakültesi Dergisi, 7.1: 153-173

Büyüköztürk, Ş, Kılıç-Çakmak, E, Akgün, Ö E, Karadeniz, Ş, Demirel, F, 2018. Bilimsel araştırma yöntemleri, Çankaya, Ankara, Türkiye

Çolakoğlu, M, 2005. Eğitim Örgütlerinde Değişim ve Liderlik. HAYEF Journal of Education, 2.1: 63-77

Gılıç F, 2015. Öğretmenlerin karar verme sürecine katılma düzeyleri, okul kültürü ve öğretmenlerin değişime hazır olma düzeyleri arasındaki ilişkinin incelenmesi. Yüksek Lisans Tezi, Mersin Üniversitesi 
Günbayı İ, 2006 İstendik davranışları destekleyen bir sınıf disiplini oluşturma: Öğrenen sinıf yapısı oluşturma, İstanbul, Türkiye, pp 209-242

Gürültü, E, Aslan, M, Alc1, B, 2020. Ortaöğretim Öğretmenlerinin 21. Yüzyıl Becerileri Kullanım Yeterlikleri. Hacettepe Üniversitesi Eğitim Fakültesi Dergisi, 35.4: 780798

Helvac1, M A, 2005. Eğitim örgütlerinde değişim yönetimi ilke, yöntem ve süreçler, Çankaya, Ankara, Türkiye

Helvac1, M A, 2015. Schools ${ }^{\text {ee }}$ Readiness towards Change. The Anthropologist International Journal of Contemporary and Applied Studies of Man, 19.3: 723-734

Helvacı, M A, Kıcıroğlu, B, 2010. İlköğretim Okullarının Değişime Hazır Bulunuşluk Düzeyleri (Uşak İli Örneği). Akademik Bakış Dergisi, 21: 1-30

Karacabey, M F, Bozkuş, K, 2018. Okul Yöneticilerinin Kaygı ve Değişime Hazır Olma Düzeyleri. International Journal of Social Sciences and Education Research, 4.2: 245-251

Karaman, M K, 2016. Öğretmen adaylarının Medya Okuryazarlık Düzeyleri ve Eleştirel Düşünme Eğilimleri Üzerine Bir Araştırma. Gümüşhane Üniversitesi İletişim Fakültesi Elektronik Dergisi, 4.1: 326-350

Kaya S, 2017. Lise öğrencilerinin 21. yüzyıl becerilerinin öğrenci tükenmişliği ve okul bağlılığı ile ilişkisi. Yüksek Lisans Tezi, Hacettepe Üniversitesi

Kılbaş, Ş, 2000. 2000'li Yıllarda Etkili Öğretmen Nasıl Olmalıdır?. Çukurova Üniversitesi Eğitim Bilimleri Fakültesi Dergisi, 2.19: 34-42

Kıyasoğlu E, 2019. Sınıf öğretmenlerinin 21. yüzyıl öğrenen ve öğreten becerileri. Yüksek Lisans Tezi, Düzce Üniversitesi

Numanoğlu, G, 1999. Bilgi Toplumu-Ĕ̆itim-Yeni Kimlikler-II Bilgi Toplumu ve Eğitimde Yeni Kimlikler. Ankara University Journal of Faculty of Educational Sciences, 32.1: 341-350

Orhan-Göksün D, 2016. Öğretmen adaylarının 21. yy. öğrenen becerileri ve 21. yy. öğreten becerileri arasındaki ilişki. Doktora Tezi, Anadolu Üniversitesi

Parlar H, 2012. Okul geliştirme literatürünün modeller ve yeni yaklaşımlar açısından incelenmesi: kuramsal analitik bir yaklaşım. Doktora Tezi, Marmara Üniversitesi

Self, D R, Armenakis, A A, Schraeder, M, 2007. Organizational Change Content, Process, and Context: A Simultaneous Analysis of Employee Reactions. Journal of Change Management, 7.2: 211-229

Yazıcı K, 2009. İlköğretim okullarında görev yapan öğretmenlerin yeni ilköğretim programları hakkındaki görüşleri ve öğretmenlerin değişime karşı gösterdikleri direnç arasındaki ilişki. Yüksek Lisans Tezi, Akdeniz Üniversitesi

Zorlu E, 2017. Okulların değişime hazır bulunuşluk düzeyleri (Afyonkarahisar ili örneği). Yüksek Lisans Tezi, Uşak Üniversitesi 
Author(s) will retain the copyright of their published articles agreeing that a Creative Commons Attribution 4.0 International License (CC BY 4.0) terms will be applied to their work. Under the terms of this license, no permission is required from the author(s) or publisher for members of the community to copy, distribute, transmit or adapt the article content, providing a proper, prominent and unambiguous attribution to the authors in a manner that makes clear that the materials are being reused under permission of a Creative Commons License. Views, opinions and conclusions expressed in this research article are views, opinions and conclusions of the author(s). Open Access Publishing Group and European Journal of Education Studies shall not be responsible or answerable for any loss, damage or liability caused in relation to/arising out of conflicts of interest, copyright violations and inappropriate or inaccurate use of any kind content related or integrated into the research work. All the published works are meeting the Open Access Publishing requirements and can be freely accessed, shared, modified, distributed and used in educational, commercial and non-commercial purposes under a Creative Commons Attribution 4.0 International License (CC BY 4.0). 